\title{
ANALYSIS OF PRINCIPLES OF SELECTION \\ OF SECONDARY WASTE SEGREGATION INSTALLATION ELEMENTS ON THE AREA OF SELECTED MUNICIPALITY
}

\author{
Grzegorz Przydatek*, Sławomir Smaga \\ Technical Institute, State Vocational School in Nowy Sącz
}

*Corresponding author: e-mail: g.przydatek@gmail.com

\begin{tabular}{ll}
\hline ARTICLE INFO & ABSTRACT \\
\cline { 2 - 2 } $\begin{array}{l}\text { Article history: } \\
\text { Received: January } 2016 \\
\text { Received in the revised form: }\end{array}$ & $\begin{array}{l}\text { In recent years systemic changes in waste management have affected } \\
\text { searching and implementation of solutions that increase waste recov- } \\
\text { May 2016 }\end{array}$ \\
$\begin{array}{l}\text { Accepted: August } 2016 \\
\text { dicted amount of municipal waste intended for recovery based on their } \\
\text { Key words: } \\
\text { municipal waste, } \\
\text { waste segregation, } \\
\text { waste sorting plant }\end{array}$ & $\begin{array}{l}\text { selected streams. For the needs of a conceptual solution the area was } \\
\text { determined, which was operated by the mentioned installation. The } \\
\text { paper uses the indicators of waste accumulation: mass, volume, bulk } \\
\text { density and irregularity of their collection in 2011-2013 for determina- } \\
\text { tion of the sorting plant efficiency. Elements of the installation, which } \\
\text { should enable optimization of the waste recovery process optimiza- } \\
\text { tion, were selected. Moreover, frames of technological efficiency of } \\
\text { the suggested solution were defined. The aim of the paper was an } \\
\text { attempt to select parameters of a municipal waste sorting plant with } \\
\text { location under conditions of Stary Sącz city. }\end{array}$ \\
\hline
\end{tabular}

\section{Introduction}

The act of 13th September 1996 on maintaining cleanness and order in municipalities (Journal of Laws of 2013, item 1399 as amended www.sejm.gov.pl), the act on waste of 14th December 2012 (Journal of Laws 2013, item 21, item 888 as amended www.sejm.gov.pl) and the National Plan of Waste Management 2010 (KPGO, 2014) include significant legal provisions concerning waste management. Systemic changes in waste management in the recent years affected the actions taken by local governments that enable the increase of waste recovery including recycling. The basic element in the rational waste management system is selective collection and segregation of waste, which, the most often is carried out with selective collection methods "at the source" and in mechanical waste sorting plants (Rosik-Dulewska, 2011; Hryb, 2011). The effect of these actions will consist in limitation of the amount of waste directed to a landfill and achievement of the required level of recovery and waste recycle.

The article presents a suggestion of a solution for obtaining the highest possible level of waste purity intended for material with optimization of the technological process of the installation. The objective of the paper was an attempt to select elements for a conceptive 
solution of secondary segregation of waste along with a location under the conditions of Stary Sącz city.

\section{Characteristics of the selected municipality}

Stary Sącz has a specific micro-climate. The land shape caused local temperature dropping particularly in the winter season and the increase of air moisture. The average annual temperature fluctuates within $6-8^{\circ} \mathrm{C}$ and the annual sum of precipitation is from $750 \mathrm{~mm}$ to $800 \mathrm{~mm}$. July is the rainiest month and the lowest amount of precipitation is in winter. There are two kinds of soils: shallow loamy soils (skeleton) and loamy average-deep. They the most often are classified to IV and V soil quality class. All forests in this area are protected - they are mainly soil protecting woods and water protecting woods (Program, www.stary.sacz.pl). The area of forest lands on the area of the city is 177.94 ha which corresponds to the forest density at the level of $11.3 \%$ (GUS, 2013). Two rivers Dunajec and Poprad flow through the area of the city and municipality.

\section{Location of the sorting plant}

Flat area far from buildings and forms of environment protection is the most recommended under the installation on account of morphology. The suggested location for a sorting plant in the eastern part of the city is slightly inclined towards north. Poprad river flows approximately $0.6 \mathrm{~km}$ on the east side to the suggested location and the state road no. 87 is located on the west side. Non-used land is present in the neighbourhood.
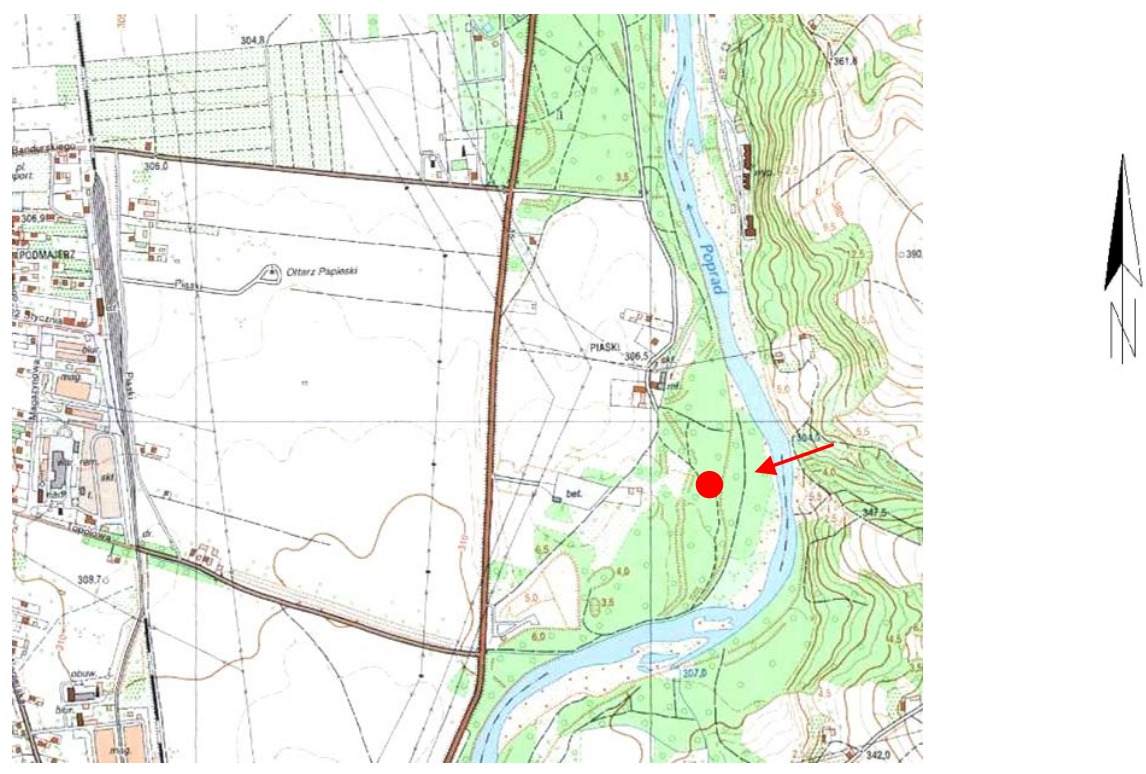

Figure 1. The proposed location of the municipal landfill site in Stary Sacz municipality (www.mapy.geoportal.gov.pl) 
Analysis of principles...

The indicated location (Fig. 1) as the only suggestion in local conditions was created based on the consultations with a municipal entity which deals with waste management on the area of Stary Sącz city and municipality.

\section{Analysis of waste productivity}

Municipal waste according to the provisions of the act on waste of 14th December 2012 (Journal of Laws of 2013, item 21, item 888 as amended) are waste produced in households except for vehicles withdrawn from exploitation and waste devoid of dangerous waste which come from other waste producers, which on account of its character or composition are similar to waste which are produced in households.

The size and structure of the generated municipal waste is affected by numerous factors, which, inter alia, (Przydatek, 2012) are:

- place of production,

- size of consumption

- wealth of people,

- nature of development,

- density of population,

- presence of the public utility facilities, trading places and small industry or services.

In order to prepare a conception solution of municipal waste recovery in a sorting plant their amount was assumed based on statistical data including dry fraction of waste separated from the stream of waste.

Knowledge on the composition of waste, including the material one, relates directly their properties with efficiency of waste management on the selected area.

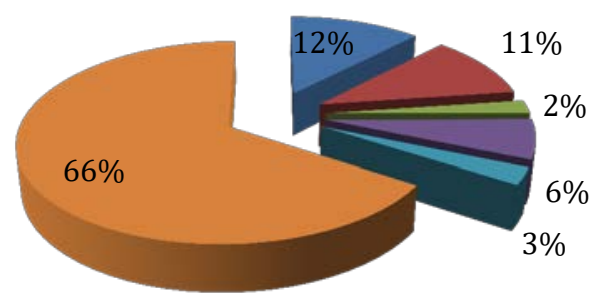

$$
\begin{aligned}
& \text { - paper and cardboard } \\
& \text { - plastics } \\
& \text { - textile } \\
& \text { - glass } \\
& \text { metal } \\
& \text { m others }
\end{aligned}
$$

Figure 2. Morphological composition of municipal waste of Stary Sacz municipality (Plan, www.stary.sacz.pl)

The predicted morphological composition of municipal waste for the selected entity in case of dry fraction of waste presents a considerable participation of paper and cardboard (12\%) and plastic (11\%) and insignificant participation (2\%) of textile (Fig. 2). Similarly, Traczewska et al., proved a considerable participation of the mentioned waste in the research which was carried out. (2014).

The basis for determination of parameters of the installation for waste management is determination of indicators of mass and volumetric collection of waste. The indicator of 
mass collection of waste is the amount of solid waste collected in a specific time unit expressed in mass units referred to one citizen, a square meter of area and another calculation unit. A volumetric indicator of waste collection is a volume of collected loose (without artificial compaction) waste in containers, expressed with volumetric units referred to one citizen, area unit or other calculation unit (Generowicz and Gąska, 2014).

\section{Calculation of parameters of a sorting plant}

Indicator of mass accumulation of waste $\left(b_{m}\right)$ is calculated based on the following formula (1):

$$
b_{m}=\frac{m}{M * d}\left(\mathrm{~kg} \cdot \mathrm{M}^{-1} \cdot \mathrm{db}^{-1}\right)\left(\mathrm{kg} \cdot \mathrm{M}^{-1} \cdot \text { year }^{-1}\right)
$$

where:

$$
\begin{array}{ll}
m & - \text { mass of the collected dry fraction of waste, } \\
M & - \text { number of citizens } \\
d & \text { - number of days of waste collection. }
\end{array}
$$

Indicator of volumetric waste collection $\left(b_{o b j}\right)$ may be calculated based on the formula

$$
b_{o b j}=\frac{\sum_{i=1}^{n} v_{i}}{M * d}\left(\mathrm{dm}^{3} \cdot \mathrm{M}^{-1} \cdot \mathrm{db}^{-1}\right)\left(\mathrm{dm}^{3} \cdot \mathrm{M}^{-1} \cdot \mathrm{year}^{-1}\right)
$$

where:

$$
\begin{array}{ll}
v i & \text { - assumed volume of waste in containers, } \\
M & \text { - number of citizens, } \\
d & \text { - number of days of waste collection. }
\end{array}
$$

\begin{tabular}{|c|c|c|c|c|c|}
\hline \multirow{5}{*}{$\begin{array}{l}\text { City and } \\
\text { Municipality } \\
\text { of Stary } \\
\text { Sącz }\end{array}$} & \multirow[t]{2}{*}{ Year } & $\begin{array}{c}\text { Mass of dry } \\
\text { fraction of } \\
\text { waste } \\
\end{array}$ & $\begin{array}{l}\text { Number } \\
\text { of citizens }\end{array}$ & $\begin{array}{l}\text { Number of days of } \\
\text { waste collection }\end{array}$ & $\begin{array}{l}\text { Assumed volume of } \\
\text { waste in containers }\end{array}$ \\
\hline & & $m\left(\mathrm{~kg} \cdot\right.$ year $\left.^{-1}\right)$ & $M$ & $d$ (days'year ${ }^{-1}$ ) & $v i\left(\mathrm{dm}^{3} \cdot\right.$ year $\left.^{-1}\right)$ \\
\hline & 2011 & $383,530.00$ & 23,181 & 365 & $927,240.00$ \\
\hline & 2012 & $355,963.00$ & 23,319 & 366 & $932,760.00$ \\
\hline & 2013 & $427,156.00$ & 23,390 & 365 & $935,600.00$ \\
\hline
\end{tabular}

Density (volumetric weight) of waste may be calculated according to the following formula (3):

$$
G=\frac{b_{m}}{b_{o b j}}\left(\mathrm{~kg} \cdot \mathrm{m}^{-3}\right)
$$

Table 1.

Input data for calculation of accumulation indicators

CSO 2011-2013; Rosik-Dulewska, 2011 
Analysis of principles...

Table 2.

Indicators of waste accumulation

\begin{tabular}{|c|c|c|c|c|c|c|}
\hline \multirow{5}{*}{$\begin{array}{l}\text { City and } \\
\text { Municipality } \\
\text { of Stary Sącz }\end{array}$} & \multirow[t]{2}{*}{ Year } & \multicolumn{2}{|c|}{$\begin{array}{c}\text { Indicators } \\
\text { of mass waste } \\
\text { accumulation }\end{array}$} & \multicolumn{2}{|c|}{$\begin{array}{c}\text { Indicators } \\
\text { of volumetric waste } \\
\text { accumulation }\end{array}$} & \multirow{2}{*}{$\begin{array}{c}\begin{array}{c}\text { Density } \\
\text { (volumetric } \\
\text { weight) } \\
\text { of waste }\end{array} \\
\begin{array}{c}G \\
\left(\mathrm{~kg} \cdot \mathrm{m}^{-3}\right)\end{array}\end{array}$} \\
\hline & & $\begin{array}{c}b_{m} \\
\left(\mathrm{~kg} \cdot \mathrm{M}^{-1} \cdot \mathrm{db}^{-1}\right) \\
\end{array}$ & $\begin{array}{c}b_{m} \\
\left.\mathrm{~kg} \cdot \mathrm{M}^{-1} \cdot \text { year }^{-1}\right)\end{array}$ & $\begin{array}{r}b_{o b j} \\
\left.\mathrm{dm}^{3} \cdot \mathrm{M}^{-1} \cdot \mathrm{db}^{-1}\right) \\
\end{array}$ & $\begin{array}{c}b_{\text {obj }} \\
\left(\mathrm{m}^{3} \cdot \mathrm{M}^{-1} \cdot \text { year }^{-1}\right) \\
\end{array}$ & \\
\hline & 2011 & 0.07 & 16.55 & 0.003 & 1.03 & 16.07 \\
\hline & 2012 & 0.06 & 15.26 & 0.003 & 1.03 & 14.82 \\
\hline & 2013 & 0.07 & 18.26 & 0.003 & 1.03 & 17.73 \\
\hline
\end{tabular}

In the analysed years 2011-2013 an increase of dry fraction mass of waste by $11 \%$ and the volume by $1 \%$ is noticeable. In comparison to the increase in the number of citizens by $1 \%$, the value of the indicator of mass accumulation of waste demonstrates the increase by $10 \%$. The remaining results of waste accumulation do not show any changes which excludes considerable irregularity of their accumulation. Comparison to literature data shows that similar results of waste collection to the proved ones were achieved by GrygorczukPetersons et al., (2014). Contrary, other researchers (Generowicz and Gąska, 2014) obtained higher values of accumulation indicators on the rural and the city area including waste which were collected non-selectively.

\section{Selection of elements of a sorting plant}

When selecting an installation one should take into consideration the size of the waste stream at the input and the expected capacity. The purpose of the installation for waste sorting is to obtain a fraction with the highest degree of purity so that a recipient obtains a product with a guaranteed quality (Wandrasz and Hryb, 2009). Significance of the installation in the local system of waste management is crucial with regard to the hierarchy of proceeding with waste and pragmatics of the technological process of machines and devices which serves for sorting and management of particular fractions of waste with a final destination for material use (Fig. 3).

Infrastructure of a sorting plant should ensure minimization of waste impact on the environment and optimization of the process of their recovery. The main elements of the installation should include sorting lines, made of the channel of a primary conveyor, horizontal conveyor of a sorting tribune and the waste packing press. Moreover, the infrastructure of the installation comprising an electromagnetic separator of ferrous metal and nonferrous metal and an optical and pneumatic separator are indicated (Bieniek et al., 2014).

In the process of manual sorting, the quality and quantity of recovered waste depends on the work of sorting staff. On the other hand, the efficiency of the automatic sorting process depends on the speed of a transporter, initial preparation of waste, distribution of waste on a conveyor, speed of the process of waste recognition and removal (Błędzki et al., 1997). 


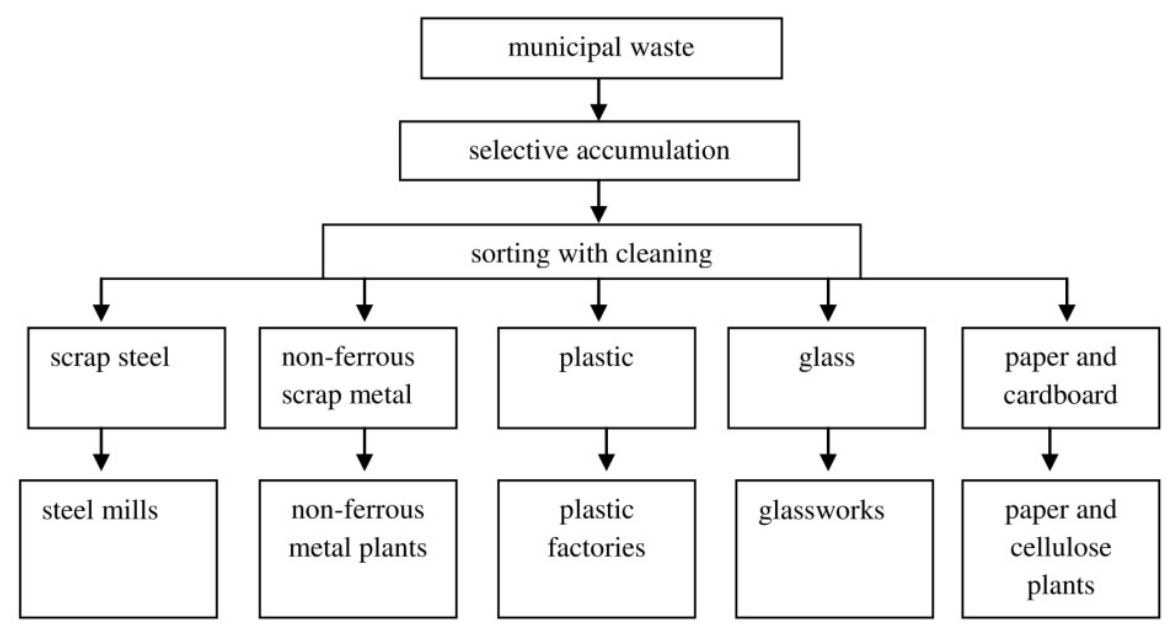

Figure 3. Diagram of the organization of the waste management system, including secondary segregation

Table 3.

Assumed parameters of sorting waste

\begin{tabular}{lccc}
\hline City and Municipality & & Performance & \\
\hline \multirow{3}{*}{ Stary Sącz } & of sorting plant & of sorting staff & $\begin{array}{c}\text { Number } \\
\text { of sorting employees }\end{array}$ \\
\cline { 2 - 3 } & $\left(\mathrm{Mg} \cdot \mathrm{db}^{-1}\right)$ & $\left(\mathrm{Mg} \cdot \mathrm{db}^{-1}\right)$ & 3 \\
\cline { 2 - 3 } & 2.00 & 0.60 & 3 \\
\hline
\end{tabular}

The daily amount of waste that may be sorted should be significant for sorting parameters (Tab. 3). Performance of a sorting plant was assumed at the level of $2 \mathrm{Mg} \cdot \mathrm{db}^{-1}$ at the assumed performance of 1 employee of $0.60 \mathrm{Mg} \cdot \mathrm{db}^{-1}$. In the sorting plant floor manual sorting of the part of dry fraction of waste is assumed. In case of the analysed installation 3 sorting stands, rising and sorting conveyor, control cabinet and compaction press and baling of recovered waste is assumed.

In the process of sorting, physical differences of waste elements properties, which may be divided, are used. Thus, the first automatic sorter is set so that it separates the selected flammable fractions of municipal waste, directed later after defragmentation as an element of alternative fuel. This separator separates the selected plastics - PE and PP and textile. The second opti-pneumatic sorter aims at separation of PET and paper which are then placed on a sorting conveyor, where employees manually separate PET with regard to colour (separately transparent, blue and green) from the paper fraction pollution is separated (Hryb, 2013). A spectrometer may be used for improvement of the process of plastic segre- 
Analysis of principles...

gation, which enables separation into plastics from the group of PE, PS, PP, PVC, PET and PA.

Also a press for baling the collected dry fraction of waste is indispensable. The role of the press is significant on account of the possibility of compaction of waste from metal, plastic and paper.

The main indicator of the efficiency of a sorting plant is a mass indicator of waste use, which presents ability for maximum processing of the mass of waste into useful raw materials and products that can be sold. Thus, it determines limitation of the stream of waste taken into a landfill. The index of use of municipal waste in the national conditions is within 21 to 83\%, thus Wandrasz and Hryb (2009) presented a formula for determination of the mass index use of municipal waste from a sorting plant (4):

$$
W_{m}=\frac{x_{1-n}}{X_{p}} * 100 \%
$$

where:

$W_{m} \quad$ - mass index of use of municipal waste from a sorting plant,

$X_{p} \quad-\quad$ total mass of municipal waste on the input to the sorting plant, (Mg)

$X_{1-n} \quad-$ total mass of sorted raw materials designed for energy, material and biological use, $(\mathrm{Mg})$

In order to ensure suitable sanitary conditions for employees, a social facility with a changing room, break room and toilets is usually built.

\section{Conclusions}

Based on the above, the following conclusions can be made:

- systemic changes in waste management indicate the possibility of construction of an installation for secondary waste recovery in order to increase the degree of purity of waste designed for recycling,

- absence of significant environmental restrictions constitutes one of premises for location of a sorting plant of waste under the conditions of the analysed municipal unit,

- the analyses which were carried out did not prove a considerable variability of waste accumulation,

- the main indicator of the selection of parameters of an installation for secondary segregation of dry waste fraction is a weight by volume with the value within 16.07-17.73 $\mathrm{kg} \cdot \mathrm{m}^{-3}$, at the assumed daily efficiency of $2.00 \mathrm{Mg}$,

- an optimal selection of elements of an installation aims at limitation of a human factor during waste recovery.

\section{References}

Bieniek, J. , Najman, E. , Romański, L. , Molendowski F. , Grabowski J. , Kończyło M. (2014). Analysis of municipal waste collected by the selected waste management establishments. Agricultural Engineering 2(150), 15-22.

Błędzki A. K. (red.) (1997). Recykling materiałów polimerowych. Warszawa, Wyd. NaukowoTechniczne, 1-236. 
Generowicz, A., Gąska K., (2014). Research on waste generation indicators for 40 thousand inhabitants community. Archives of Waste Management and Environmental protection Vol. 16, Issue 2, ISSN 1733-4381.

Główny Urząd Statystyczny. (2013). Rolnictwo, Leśnictwo, Łowiectwo

Grygorczuk-Petersons, E.H., Wiater, J. (2014). Sezonowa zmienność wskaźnika nagromadzenia odpadów w wybranym osiedlu Białegostoku. Inżynieria Ekologiczna, Vol. 40, 82-91.

Hryb, W. (2011). Utilization of selected fractions from biodegradable municipal waste for reclamation of degraded areas. Archives of Waste Management and Environmental Protection. Vol. 13, Issue 4, ISSN 1733-4381.

Hryb, W. (2013). Modernization of waste management plants exemplified by installation in Gorzów Wielkopolski. Archives of Waste Management and Environmental Protection. Vol. 15, Issue 1 , ISSN 1733-4381.

National Plan of Waste Management [Krajowy Plan Gospodarki Odpadami] 2014 (MP Nr 101 z 2010 r. poz. 1183).

Waste Management Plan for 2004-2011 with a forecast to 2015 for the City and Municipality of Stary Sącz (2004) [Plan Gospodarki Odpadami na lata 2004-2011 wraz z prognoza do roku 2015 dla Miasta i Gminy Stary Sacz (2004)]. Obtained from: www.stary.sacz.pl

Program Ochrony Środowiska dla Miasta i Gminy Stary Sącz na lata 2004-2011 wraz z prognozą do roku 2015 (2004). Gmina Stary Sącz. Maszynopis.

Przydatek, G. (2012). Analiza zmian systemowych w gospodarce odpadami komunalnymi na szczeblu gminnym. Autobusy, 10, 109-114.

Rosik-Dulewska, Cz. (2011). Podstawy Gospodarki Odpadami. Warszawa, Wydawnictwo Naukowe PWN, ISBN 978-83-01-165353-2

Traczewska, T.M., Kaźmierczak, B. (red.) (2014). Interdyscyplinarne zagadnienia w inżynierii i ochronie środowiska. Tom 4. Oficyna Wydawnicza Politechniki Wrocławskiej, 996-1013.

The act of 13 September 1996 o on maintaining cleanness and order in municipalities (Journal of Laws of 2013 item 1399 as amended),

The act of 14 December 2012 r. on waste (Journal of Laws of 2013 r. item 21, 888 as amended.).

Wandrasz, J.W., Hryb, W. (2009). Kierunki rozwoju nowoczesnych instalacji w systemie Zakładów Zagospodarowania Odpadów. Archives of Waste Management and Environmental Protection Vol. 11, Issue 2, ISSN 1733-4381.

http://geoportal.gov.pl/ dostęp (20.03.2015r)

http://www.recyklingwojkowice.pl/ dostęp (28.04.2015r)

\section{ANALIZA ZALOŻEŃ DOBORU SKLADOWYCH INSTALACJI DO WTÓRNEJ SEGREGACJI ODPADÓW NA TERENIE WYBRANEJ GMINY}

Streszczenie. Zmiany systemowe w gospodarce odpadami w ostatnich latach wpływają na poszukiwanie i wdrażanie rozwiązań zwiększających odzysk odpadów, w tym przeznaczanych do recyklingu. W artykule zawarto przewidywaną do odzysku ilość odpadów komunalnych na podstawie wybranych ich strumieni. Dla potrzeb koncepcyjnego rozwiązania wyznaczono obszar, który byłby obsługiwany przez wspomnianą instalację. W pracy wykorzystano wskaźniki nagromadzenia odpadów: masowy, objętościowy i gęstość nasypową, a także rozpoznano nierównomierność ich nagromadzenia w latach 2011-2013 dla wyznaczenia wydajności sortowni. Dobrano części składowe instalacji, które powinny umożliwić optymalizację procesu odzysku odpadów. Określono również ramy efektywności technologicznej zaproponowanego rozwiązania. Celem pracy była próba doboru parametrów sortowni odpadów komunalnych wraz z lokalizacją w warunkach miasta Stary Sącz.

Słowa kluczowe: odpady komunalne, segregacja odpadów, sortowania odpadów 